\title{
BIBLIOGRAPHY OF WORKS CITED
}

Ackrill, J. L. "Aristotle on Eudaimonia." Proceedings of the British Academy 60 (1974): 339-359.

Acton, H. B., ed. The Philosophy of Punishment. New York: St. Martin's Press, 1969.

Anscombe, G. E. M. "Modern Moral Philosophy." Philosophy 33 (January 1958): $1-19$.

Austin, J. L. How to Do Things with Words. Ed. J. O. Urmson and Marina Sbisà. 2d ed. Cambridge, Mass.: Harvard University Press, 1977 .

Axelrod, Robert. "The Emergence of Cooperation among Egoists." American Political Science Review 75 (June 1981): 306-31 8.

Axtell, James L., ed. The Educational Writings of Jobn Locke. Cambridge: Cambridge University Press, 1968.

Ayers, M. R. "Mechanism, Superaddition, and the Proof of God's Existence in Locke's Essay." Philosophical Review 90 (April 1981): 208-25I.

Barry, Brian. "Warrender and His Critics." Pbilosophy 43 (April I968): II 7- 137 .

Baumgardt, David. Bentham and the Ethics of 'Today. Princeton, N.J.: Princeton University Press, 1952.

Becker, Carl L. Modern Democracy. New Haven, Conn.: Yale University Press, 1942.

Bentham, Jeremy. Deontology. Ed. John Bowring. 2 vols. London, 1834 . 
An Introduction to the Principles of Morals and Legislation. Ed. J. H. Burns and H. L. A. Hart. London: Athlone Press, 1970.

. Works of Jeremy Bentham. Ed. John Bowring. I I vols. New York: Russell \& Russell, 1962.

Borges, Jorge Luis, and Adolfo Bioy-Casares. Chronicles of Bustos Domecq. Trans. Norman Thomas di Giovanni. New York: Dutton, I 976.

Botwinick, Aryeh. "A Case for Hume's Nonutilitarianism." Journal of the History of Philosophy 15 (October 1977): 42 3-435.

Bradley, F. H. Ethical Studies. 2d ed. Oxford: Clarendon, 1967.

Brandt, Richard B. Ethical Theory. Englewood Cliffs, N.J.: PrenticeHall, 1959.

- A Theory of the Good and the Right. Oxford: Clarendon, 1979.

Brown, K. C., ed. Hobbes Studies. Oxford: Basil Blackwell, 1965.

Brown, Stuart M., Jr. "Hobbes: The 'Taylor Thesis." Philosophical Review 68 (July 1959): 303-323.

[Burnet, Thomas.] Remarks upon an Essay concerning bumane understanding. London, 1697.

Campbell, Blair. "Prescription and Description in Political Thought: The Case for Hobbes." American Political Science Review 65 (June 1971): 376-388.

Catlin. George. Thomas Hobbes as Philosopher, Publicist, and Man of Letters. Oxford: Basil Blackwell, 1922.

Churchland, Paul M. Scientific Realism and the Plasticity of Mind. Cambridge: Cambridge University Press, 1979.

Cohen, Marshall, Thomas Nagel, and Thomas Scanlon, eds. War and Moral Responsibility. Princeton, N.J.: Princeton University Press, 1974.

Conniff, James. "Hume on Political Parties: The Case for Hume as a Whig." Eighteenth-Century Studies 12 (Winter 1978-79): 1 50- 173.

Cooper, John M. Reason and Human Good in Aristotle. Cambridge, Mass.: Harvard University Press, 1975.

Cropsey, Joseph. Polity and Economy: An Interpretation of the Principles of Adam Smith. Westport, Conn.: Greenwood, 1977.

Daniels, Norman, ed. Reading Rawls. New York: Basic Books, n.d.

Davidson, Donald, J. C. C. McKinsey, and Patrick Suppes. "Outlines of a Formal Theory of Value, I." Philosophy of Science 22 (April 1955): 140- 160.

Day, J. P. “Locke on Property.” Philosophical Quarterly i 6 (July I 966): 207-220.

Dick, Oliver Lawson, ed. Aubrey's Brief Lives. London: Secker and Warburg, 1950. 


\section{BIBLI OGRAPHY OF WORKS CITED}

Dunn, John. "Consent in the Political Theory of John Locke." Historical Journal io (1 967): 1 53-i 82.

. "Justice and the Interpretation of Locke's Political Theory." Political Studies I 8 (February I968): 68-87.

. The Political Thought of Jobn Locke. Cambridge: Cambridge University Press, 1969.

Dworkin, Ronald. Taking Rights Seriously. Cambridge, Mass.: Harvard University Press, I980.

Foot, Philippa. Virtues and Vices and Other Essays in Moral Philosophy. Berkeley: University of California Press, 1978.

Forbes, Duncan. Hume's Philosophical Politics. Cambridge: Cambridge University Press, 1975.

Fullinwider, Robert K. "Fanaticism and Hare's Moral Theory." Ethics 87 (January 1977): 165-173.

Gauthier, David. "David Hume, Contractarian." Philosophical Review 88 (January 1979): 3-38.

. The Logic of Leviatban. Oxford: Clarendon, 1969.

(October 1979): 547-559.

- "Why Ought One Obey God? Reflections on Hobbes and Locke." Canadian Journal of Pbilosophy 7 (September 1977): 425-446.

Geertz, Clifford. The Interpretation of Cultures. New York: Basic Books, 1973.

. Local Knowledge. New York: Basic Books, 1983.

Gettner, Alan. "Hare and Fanaticism." Ethics 87 (January 1977): $160-164$.

Gutmann, Amy. Liberal Equality. Cambridge: Cambridge University Press, 1980.

Haakonssen, Knud. The Science of a Legislator: The Natural Jurisprudence of David Hume and Adam Smith. Cambridge: Cambridge University Press, 198I.

Hacker, P. M. S., and J. Raz, eds. Law, Morality, and Society. Oxford: Clarendon, 1979.

Hall, Everett W. "The 'Proof' of Utility in Bentham and Mill." Etbics 60 (October 1949): I-I8.

Hare, R. M. Applications of Moral Pbilosophy. Berkeley: University of California Press, 1973.

- Essays on the Moral Concepts. Berkeley: University of California Press, 1973.

nia Press, 1972. 
. Freedom and Reason. Oxford: Clarendon, 1963.

. The Language of Morals. Oxford: Clarendon, 1952.

. Moral Thinking. Oxford: Clarendon, 198I.

- "The Promising Game." Revue internationale de philosophie 18 (1964): 398-4I2.

- "Rawls' Theory of Justice." Pbilosophical Quarterly 23 (April

1973): 144-1 55; 23 (July 1973): 24I-252.

- "Rules of War and Moral Reasoning." Pbilosophy \& Public Affairs I (Winter I 972): I66-I8I.

. "What Is Wrong with Slavery." Pbilosophy \& Public Affairs 8 (Winter 1979): 103-121.

- "What Makes Choices Rational?" Review of Metaphysics 32 (June 1979): 623-637.

Harrison, Jonathan. Hume's Moral Epistemology. Oxford: Clarendon, 1976.

. Hume's Theory of Justice. Oxford: Clarendon, I98I.

Harrod, R. F. "Utilitarianism Revised." Mind 45 (April 1936): $137-156$.

Harsanyi, John C. "Cardinal Welfare, Individualistic Ethics, and Interpersonal Comparisons of Utility." Journal of Political Economy 63 (August 1955): 309-32 I.

- Essays on Ethics, Social Behavior, and Scientific Explanation. Dordrecht, Holland: D. Reidel, 1976.

—. "Ethics in Terms of Hypothetical Imperatives." Mind 67 (July 1958): 305-3 16.

. "Morality and the Theory of Rational Behavior." Social Research 44 (Winter 1977): 623-656.

_. "Nonlinear Social Welfare Functions: Do Welfare Economists Have a Special Exemption from Bayesian Rationality?" Theory and Decision 6 (August 1975): 31 1-332.

- Rational Behavior and Bargaining Equilibrium in Games and Social Situations. Cambridge: Cambridge University Press, 1977.

Hart, H. L. A. The Concept of Law. Oxford: Clarendon, 1975.

Hirschman, Albert O. Shifting Involvements. Princeton, N.J.: Princeton University Press, 1982.

Hobbes, Thomas. A Dialogue between a Pbilosopher and a Student of the Common Laws of England. Ed. Joseph Cropsey. Chicago: University of Chicago Press, I97 I.

- The Elements of Law Natural and Politic. Ed. Ferdinand Tönnies. 2d ed. New York: Barnes \& Noble, 1969.

. The English Works of Thomas Hobbes. Ed. William Molesworth. I I vols. London, I 839- I 845 . 
Hobbes's Leviathan. With an essay by the late W. G. Pogson Smith. Oxford: Clarendon, 1967.

. Leviathan. Ed. C. B. Macpherson. Harmondsworth: Penguin, 1968.

- "The Life of 'Thomas Hobbes of Malmesbury." 'Trans. J. E. Parsons, Jr., and Whitney Blair. Interpretation Io (January 1982): I -7 .

- Man and Citizen. Ed. Bernard Gert. New York: Doubleday, 1972.

Hubin, D. Clayton. "The Scope of Justice." Pbilosophy \& Public Affairs 9 (Fall 1979): 3-24.

Hudson, W. D., ed. The Is-Ought Question. New York: St. Martin's Press, 1969.

Hume, David. Enquiries concerning Human Understanding and concerning the Principles of Morals. Ed. L. A. Selby-Bigge. 3 rd ed. rev. by P. H. Nidditch. Oxford: Clarendon, 1978.

- Essays: Moral, Political, and Literary. Great Britain: Oxford University Press, 1974.

- History of England. New ed. 6 vols. Boston: Little, Brown, 1872 .

. The Letters of David Hume. Ed. J. Y. T. Grieg. 2 vols. Oxford: Clarendon, 1969.

- The Natural History of Religion and Dialogues concerning Natural Religion. Ed. A. Wayne Colver and John Valdimir Price. Oxford: Clarendon, 1976.

- A Treatise of Human Nature. Ed. L. A. Selby-Bigge. $2 \mathrm{~d}$ ed. rev. by P. H. Nidditch. Oxford: Clarendon, 1980.

Irwin, Terence. Plato's Moral Theory. Oxford: Clarendon, 1977.

James, William. The Meaning of Truth. Cambridge, Mass.: Harvard University Press, 1975.

—. Pragmatism. Cambridge, Mass.: Harvard University Press, 1975.

Jeffrey, Richard C. "On Interpersonal Utility Theory." Journal of Pbilosophy 68 (October 21, 197 I): 647-656.

Jervis, Robert. "Cooperation under the Security Dilemma." World Politics 30 (January 1978): I67-2 I4.

King, Lord. The Life of Jobn Locke. London, 1829.

Kramnick, Isaac. Bolingbroke and His Circle. Cambridge, Mass.: Harvard University Press, 1968.

. The Rage of Edmund Burke. New York: Basic Books, 1977.

Kretzmann, Norman. "Desire as Proof of Desirability." Pbilosophical Quarterly 8 (July 1958): 246-258. 
Krook, Dorothea. "Thomas Hobbes's Doctrine of Meaning and Truth." Philosopby 3 I (January 1956): 3-32.

Laslett, Peter, ed. Philosophy, Politics and Society. i st ser. Oxford: Basil Blackwell, 1967.

Laslett, Peter, W. G. Runciman, and Quentin Skinner, eds. Philosophy, Politics and Society. 4th ser. London: Basil Blackwell, 1972.

Lewis, H. D., ed. Contemporary British Pbilosophy. 4th ser. London: Allen \& Unwin, 1976.

Lively, Jack, and John Rees, eds. Utilitarian Logic and Politics. Oxford: Clarendon, 1978.

Locke, Don. "The Trivializability of Universalizability." Philosophical Review 77 (January 1968): 25-44.

Locke, John. Epistola de Tolerantia: A Letter on Toleration. Ed. Raymond Klibansky. Trans. J. W. Gough. Oxford: Clarendon, 1968.

- An Essay concerning Human Understanding. Ed. Peter $\mathrm{H}$. Nidditch. Clarendon ed. Oxford: Clarendon, 1979.

. Essays on the Law of Nature. Ed. and trans. W. von Leyden. Oxford: Clarendon, 1954.

- Two Tracts on Government. Ed. Philip Abrams. Cambridge: Cambridge University Press, 1967.

- Two Treatises of Government. Ed. Peter Laslett. 2d ed. Cambridge: Cambridge University Press, 1970.

- The Works of John Locke. Io vols. London, 1823.

Luce, R. Duncan, and Howard Raiffa. Games and Decisions. New York: Wiley, 1957 .

Lyons, David. Forms and Limits of Utilitarianism. Oxford: Clarendon, 1965 .

. In the Interest of the Governed: A Study in Bentham's Philosophy of Utility and Law. Oxford: Clarendon, 1973.

Lyons, William. "Against an Orthodox Interpretation of Hobbes." Pbilosopbical Quarterly 27 (October 1977): 302-31 2.

MacIntyre, Alasdair. After Virtue. Notre Dame, Ind.: University of Notre Dame Press, 198I.

MacKay, Alfred F. "Interpersonal Comparisons." Journal of Pbilosophy 72 (October 2, 1975): 535-549.

Mackie, J. L. The Cement of the Universe. Oxford: Clarendon, 1980.

- Etbics: Inventing Right and Wrong. Harmondsworth: Penguin, 1977. 1980.

Hume's Moral Theory. London: Routledge \& Kegan Paul, The Miracle of Theism. Oxford: Clarendon, 1982. Problems from Locke. Oxford: Clarendon, 1976. 
I976): $317-327$.

McNeilly, F. S. The Anatomy of Leviathan. London: Macmillan, 1968.

Macpherson, C. B. The Political Theory of Possessive Individualism. Oxford: Clarendon, 1962.

- "The Social Bearing of Locke's Political Theory." Western Political Quarterly 7 (March 1954): I - 22.

Mansfield, Harvey C., Jr. "Hobbes and the Science of Indirect Government." American Political Science Review 65 (March 197 I): 97- I I 0.

Martin, Rex. "A Defence of Mill's Qualitative Hedonism." Philosophy 47 (April 1972): 140-15I.

Mill, John Stuart. Autobiography and Literary Essays. Ed. John M. Robson and Jack Stillinger. Collected Works. Vol. I. Toronto: University of 'Toronto Press, 198I.

- Essays on Ethics, Religion, and Society. Ed. J. M. Robson. Collected Works. Vol. io. Toronto: University of Toronto Press, 1969.

. Essays on Politics and Society. Ed. J. M. Robson. Collected Works.

Vols. 18-19. Toronto: University of Toronto Press, 1977.

—. A System of Logic. Ed. J. M. Robson. Collected Works. Vols. 7-8. Toronto: University of 'Toronto Press, 1973.

Miller, David. Philosophy and Ideology in Hume's Political T'bought. Oxford: Clarendon, $198 \mathrm{I}$.

Mintz, Samuel. T'be Hunting of Leviathan. Cambridge: Cambridge University Press, 1962.

Moore, G. E. Ethics. New York: Oxford University Press, 1965.

—. Principia Etbica. Cambridge: Cambridge University Press, 1980.

Mossner, Ernest Campbell. Adaim Smith: The Biographical Approach. Glasgow: University of Glasgow Press, 1969.

- "Was Hume a Tory Historian? Facts and Reconsiderations." Journal of the History of Ideas 2 (April 1941): 225-236.

Nagel, Thomas. "Hobbes's Concept of Obligation." Pbilosopbical Review 68 (January 1959): 68-83.

Narveson, Jan. "Liberalism, Utilitarianism, and Fanaticism: R. M. Hare Defended." Etbics 88 (April 1978): 250-259.

Nell, Onora. Acting on Principle. New York: Columbia University Press, 1975.

Nozick, Robert. Anarchy, State, and Utopia. New York: Basic Books, I974.

\footnotetext{
- Pbilosophical Explanations. Cambridge, Mass.: Harvard University Press, Belknap Press, 198I.
} 
Oakeshott, Michael. Hobbes on Civil Association. Berkeley: University of California Press, 1975.

O’Meara, Dominic J., ed. Studies in Aristotle. Washington, D.C.: Catholic University of America Press, 198 I.

Patrides, C. A., ed. The Cambridge Platonists. Cambridge, Mass.: Harvard University Press, 1970.

Pennock, J. Roland. “Hobbes's Confusing 'Clarity' - The Case of Liberty." American Political Science Review 54 (June 1960): 428-436.

Peters, Richard. Hobbes. Harmondsworth: Penguin, 1956.

Pitkin, Hanna. "Obligation and Consent." American Political Science Review 59 (December 1965): 990-999; 6o (March 1966): 39-56.

Plamenatz, John. “Mr. Warrender's Hobbes." Political Studies 5 (October 1957): 295-308.

Pocock, J. G. A. The Ancient Constitution and the Feudal Law. New York: Norton, 1967.

Popkin, Richard H. "A Note on the 'Proof' of Utility in J. S. Mill." Ethics 6 I (October 1950): 66-68.

Price, John Valdimir. The Ironic Hume. Austin: University of Texas Press, 1965.

Price, Richard. A Review of the Principal Questions in Morals. Ed. D. D. Raphael. Oxford: Clarendon, I974.

Prichard, H. A. "Does Moral Philosophy Rest on a Mistake?" Mind 2 I (January I9I 2): 2 I - 37.

- Moral Obligation. Oxford: Clarendon, 197 I.

Quinton, Anthony. "On Punishment." Analysis I 4 (June 1954): 133-142.

Raphael, D. D. "Adam Smith and 'The Infection of David Hume's Society.'" Journal of the History of Ideas 30 (April-June 1969): 225248.

$\longrightarrow$, ed. British Moralists. 2 vols. Oxford: Clarendon, 1969.

Rawls, John. A Theory of Justice. Cambridge, Mass.: Harvard University Press, Belknap Press, 197 I.

- "Two Concepts of Rules." Pbilosophical Review 64 (January 1955): 3-32.

Read, Herbert. Anarchy and Order. Boston: Beacon Press, 197 I.

Riley, Patrick. Will and Political Legitimacy. Cambridge, Mass.: Harvard University Press, 1982.

Rorty, Amélie Oksenberg, ed. Essays on Aristotle's Ethics. Berkeley: University of California Press, 1980.

Rorty, Richard. Philosophy and the Mirror of Nature. Princeton, N.J.: Princeton University Press, 1979. 


\section{BIBLIOGRAPHY OF WORKS CITED}

Rosenblum, Nancy. Bentbam's Theory of the Modern State. Cambridge, Mass.: Harvard University Press, 1978.

Ross, W. D. The Right and the Good. Oxford: Clarendon, 1973.

Ryan, Alan, ed. The Idea of Freedom. Oxford: Oxford University Press, 1979.

Schelling, Thomas C. Micromotives and Macrobehavior. New York: Norton, 1978.

Schochet, Gordon J., ed. Life, Liberty, and Property: Essays on Locke's Political Ideas. Belmont, Calif.: Wadsworth, 197 I.

Searle, John R. "How to Derive Ought from Is." Philosophical Review 73 (January 1964): 43-58.

Selby-Bigge, L. A., ed. British Moralists. 2 vols. Oxford, 1897.

Sidgwick, Henry. Elements of Politics. $4^{\text {th }}$ ed. London: Macmillan, 1919.

."The Establishment of Ethical First Principles." Mind 4 (January I 879): 106-i I I.

. The Metbods of Ethics. $7^{\text {th }}$ ed. Chicago: University of Chicago Press, 1962.

Simmons, A. John. Moral Principles and Political Obligations. Princeton, N.J.: Princeton University Press, 1979.

. "The Principle of Fair Play." Pbilosophy \& Public Affairs 8 (Summer 1979): 307-337.

- "Tacit Consent and Political Obligation." Philosophy \& Public Affairs 5 (Spring 1976): 274-291.

Singer, Peter. "Is Act-Utilitarianism Self-Defeating?" Philosophical Review 8I (January 1972): 94- I04.

. "Sidgwick and Reflective Equilibrium." Monist 58 (July 1974): 490-5I7.

Skinner, Andrew. "Natural History in the Age of Adam Smith." Political Studies 15 (February 1967): 32-48.

Skinner, Andrew, and Thomas Wilson, eds. Essays on Adam Smith. Oxford: Clarendon, 1975.

Smart, J. J. C., and Bernard Williams. Utilitarianism: For and Against. Cambridge: Cambridge University Press, 1973.

Smith, Adam. The Correspondence of Adam Smith. Ed. Ernest Campbell Mossner and Ian Simpson Ross. Glasgow ed. Oxford: Clarendon, 1977 .

. Essays on Philosophical Subjects. Ed. W. P. D. Wightman and J. C. Bryce. Glasgow ed. Oxford: Clarendon, 1980.

. An Inquiry into the Nature and Causes of the Wealth of Nations. Ed. R. H. Campbell, A. S. Skinner, and W. B. Todd. Glasgow ed. 2 vols. Oxford: Clarendon, 1979. 
- Lectures on Jurisprudence. Ed. R. L. Meek, D. D. Raphael, and P. G. Stein. Glasgow ed. Oxford: Clarendon, 1978.

. Lectures on Rhetoric and Belles Lettres. Ed. J. C. Bryce. Glasgow ed. Oxford: Clarendon, 1983.

. The Theory of Moral Sentiments. Ed. D. D. Raphael and A. L. Macfie. Glasgow ed. Oxford: Clarendon, 1976.

Smith, Norman Kemp. The Philosophy of David Hume. London: Macmillan, I94I.

Spencer, Herbert. Social Statics. New York: Schalkenbach, 1970.

Spooner, Lysander. No Treason. Colorado Springs: Ralph Myles, I 973.

Spragens, Thomas A., Jr. The Politics of Motion: The World of Thomas Hobbes. Great Britain: University Press of Kentucky, 1973.

Strauss, Leo. Natural Right and History. Chicago: University of Chicago Press, 1953.

ford: Clarendon, 1936.

Strauss, Leo, and Joseph Cropsey, eds. History of Political Philosophy. 2d ed. Chicago: Rand McNally College Publishing, 1972.

Taylor, A. E. "The Ethical Doctrine of Hobbes." Philosopby 13 (October 1938): 406-424.

['Trenchard, John, and 'Thomas Gordon.] Cato's Letters. 4 vols. London, 1724.

Tucker, Josiah. A Treatise concerning Civil Government. New York: Augustus M. Kelley, 1967.

Ullmann, Walter. Medieval Political Thought. Harmondsworth: Penguin, 1975 .

von Leyden, W. "John Locke and Natural Law." Philosophy 3 I (January 1956): 23-35.

Waldman, Theodore. "A Note on John Locke's Concept of Consent." Ethics 68 (October 1 957): 45-50.

Waldner, Ilmar. "The Empirical Meaningfulness of Interpersonal Utility Comparisons." Journal of Philosophy 69 (February 24, 1972): 87-103.

Walzer, Michael. Spheres of Justice. New York: Basic Books, ${ }_{1983}$.

Warrender, Howard. The Political Philosophy of Hobbes. Oxford: Clarendon, 1957.

Watkins, J. W. N. Hobbes's System of Ideas. London: Hutchinson University Library, 1965.

_. "Philosophy and Politics in Hobbes." Philosopbical Quarterly 5 (April 1955): 125-146.

Weber, Max. From Max Weber. Trans. H. H. Gerth and C. Wright Mills. New York: Oxford University Press, 1980. 
. The Protestant Ethic and the Spirit of Capitalism. Trans. Talcott Parsons. New York: Scribner's, 1956.

Weinberger, J. "Hobbes's Doctrine of Method." American Political Science Review 69 (December 1975): 1 336-1 353.

Weldon, T. D. The Vocabulary of Politics. Baltimore: Penguin, 1960.

West, E. G. "Adam Smith's 'Two Views of the Division of Labour." Economica 31 (February 1964): 23-32.

West, Henry R. "Mill's Qualitative Hedonism." Pbilosophy 5 I (January 1976): 97-101.

White, Morton. What Is and What Ought to Be Done. New York: Oxford University Press, 198I.

Williams, Michael. Groundless Belief. Oxford: Basil Blackwell, 1977.

Wills, Garry. Explaining America. Garden City, N.Y.: Doubleday, I98I.

Winch, Donald. Adam Smitb's Politics. Cambridge: Cambridge University Press, 1979.

Wittgenstein, Ludwig. On Certainty. Ed. G. E. M. Anscombe and G. H. von Wright and trans. Denis Paul and G. E. M. Anscombe. New York: Harper \& Row, 1976.

Wolff, Robert Paul. "A Critique and Reinterpretation of Marx's Labor Theory of Value." Philosophy \& Public Affairs ro (Spring 198I): 89- 120.

- In Defense of Anarchism. New York: Harper \& Row, 1976.

Wolin, Sheldon. Hobbes and the Epic T'radition of Political Theory. Los Angeles: University of California Press, 1970.

- "Hume and Conservatism." American Political Science Review 48 (December 1954): 999- I016.

Politics and Vision. Boston: Little, Brown, 1960.

Yolton, John W., ed. Jobn Locke: Problems and Perspectives. Cambridge: Cambridge University Press, 1969. 